\title{
STUDY OF MECHANICAL PROPERTIES OF ELECTRICAL STEEL GRADE USING METHODS OF PHYSICAL AND MATHEMATICAL MODELING
}

\author{
${ }^{1}$ Anna LEVYKINA, ${ }^{2}$ Marcin KNAPINSKI, ${ }^{1}$ Igor MAZUR \\ ${ }^{1}$ LSTU - Lipetsk State Technical University, Lipetsk, Russia, RU, levykina ag@stu.lipetsk.ru \\ ${ }^{2}$ CUT - Czestochowa University of Technology, Czestochowa, Poland, PL, marcin.knapinski@pcz.pl
}

https://doi.org/10.37904/metal.2021.4102

\begin{abstract}
Electrical steel sheet is an important material in the manufacture of various parts of electrical devices with high magnetic properties. The need to form the desired properties of the metal makes special demands on the organization of the production technology for both hot-rolled and cold-rolled sheets. The combined use of physical and mathematical research methods makes it possible to more accurately study various aspects of the formation of steel characteristics in order to improve its production technology.

This paper presents the results of mechanical tests of an electrical steel grade obtained on the installation of the Gleeble 3800 for plane-strain compression. The tests were conducted at temperatures of deformation from 700 to $1250{ }^{\circ} \mathrm{C}$ and strain rates from 0.1 to $150 \mathrm{~s} \mathrm{~s}^{-1}$ on samples in the parallelepiped form; as a result, curves of the dependence of the metal flow stress on the true deformation were obtained. Based on the results of physical modeling, a mathematical model was developed in the program «Deform 3D», which repeats the tests for plane-strain compression, in order to check the adequacy of the model. The curves of the dependence of the metal flow stress on the true deformation can be used to analyze the technological modes of hot rolling of electrical steel grades, and the developed mathematical model can be used to simulate the thermal state of the metal during the formation of inhomogeneity of properties on long flat products.
\end{abstract}

Keywords: Metal forming, electrical steel, plane-strain compression, modeling

\section{INTRODUCTION}

Electrical steel is an alloy of iron with silicon, the percentage of which varies from 0.8 to $4.8 \%$ [1-2]. This material has unique magnetic properties and is widely used in the energy industry, in particular in the manufacture of transformers and magnetic cores in electrical machines.

Electrical steel sheet is an important material in the manufacture of various parts of electrical devices. The constant tightening of requirements for the quality of manufactured products predetermines the need to organize the production technology for hot-rolled and cold-rolled sheets. The presence of silicon in steel makes it possible to carry out high-temperature processing of this material, which is necessary to control the structure of the metal [3], but at the same time, this leads to a sharp decrease of plasticity [4], and therefore it can complicate the process of deformation of the metal and obtaining finished products in the whole. To solve problems aimed at obtaining rolled products with a given set of properties, a modern approach to research is required. This is especially important, when predicting the formation of inhomogeneity of metal properties on long products. One of these methods is the combined use of physical and mathematical modeling.

The purpose of the work is to study the mechanical properties of electrical steel using experimental research and mathematical modeling. 


\section{CONDUCTING RESEARCH BY THE METHOD OF PHYSICAL SIMULATION}

Experimental researches on plane-strain compression tests were carried out at the Czestochowa University of Technology (Czestochowa, Poland) on the Gleeble 3800 using the Hydrawdge module [5]. For physical modeling samples in the form of a parallelepiped with dimensions of $10 \mathrm{~mm} \times 15 \mathrm{~mm} \times 20 \mathrm{~mm}$ from E3A steel grade was used, the chemical composition of which is shown in Table 1. The width of the deformation zone was $5 \mathrm{~mm}$. For reduce the friction between the sample and the die, tantalum and graphite plates were placed, and graphite grease was also used.

Table 1 The chemical composition of E3A steel grade, \%

\begin{tabular}{|c|c|c|c|c|c|c|c|c|c|c|c|}
\hline $\mathbf{C}$ & $\mathbf{S i}$ & $\mathbf{M n}$ & $\mathbf{S}$ & $\mathbf{P}$ & $\mathbf{A l}$ & $\mathbf{C r}$ & $\mathbf{N i}$ & $\mathbf{C u}$ & $\mathbf{T i}$ & $\mathbf{N}$ & $\mathbf{S n}$ \\
\hline 0.033 & 3.16 & 0.31 & 0.006 & 0.013 & 0.018 & 0.02 & 0.02 & 0.54 & 0.003 & 0.012 & 0.004 \\
\hline
\end{tabular}

The research was carried out according to the scheme on Figure 1: the samples were heated at a heating rate of $5{ }^{\circ} \mathrm{C} / \mathrm{s}$ to a deformation temperature of $700-1250{ }^{\circ} \mathrm{C}$, then exposure was carried out for $15-125 \mathrm{~s}$, next the samples were deformed for temperatures of $700-1250{ }^{\circ} \mathrm{C}$ and strain rates of $0.1-150 \mathrm{~s}^{-1}$ and after that there was accelerated air cooling.

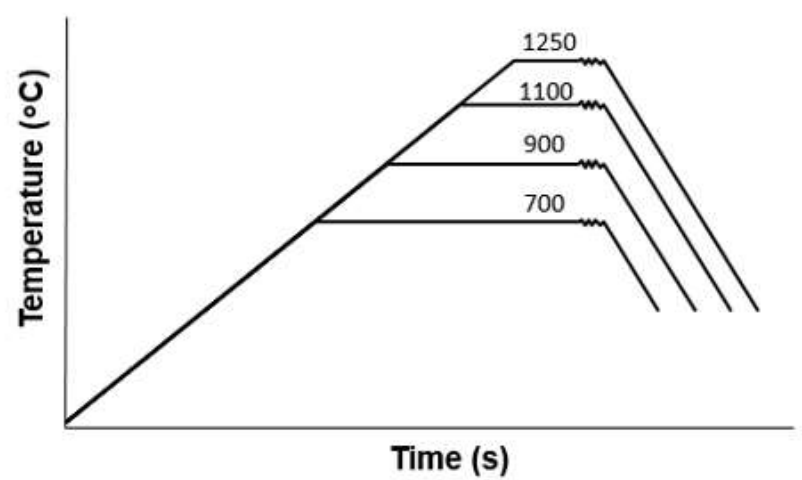

a)

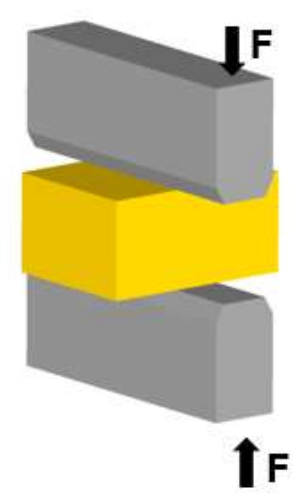

b)

Figure 1 The scheme of research (a) and the scheme of plane-strain compression test (b) on the Gleeble 3800

The values of the true strain and the flow stress of the metal during plane-strain compression tests were calculated using the formulas [6]:

$\varepsilon=\frac{2}{\sqrt{3}} \ln \left|\frac{h}{h_{0}}\right|$

$\sigma=\frac{\sqrt{3}}{2} \frac{F}{w \cdot b}$,

where:

$$
\begin{aligned}
& \varepsilon-\text { true strain }(-) \\
& h \text { - the initial height of sample }(\mathrm{mm}) \\
& h_{0}-\text { the final height of sample }(\mathrm{mm}) \\
& \sigma-\text { flow stress }(\mathrm{MPa}) \\
& F-\text { force }(\mathrm{N}) \\
& w-\text { the width of the deformation zone }(\mathrm{mm}) \\
& b-\text { the length of the sample }(\mathrm{mm})
\end{aligned}
$$


The result of the research are the curves of the dependence of flow stress of the metal on the true strain (Figure 2).
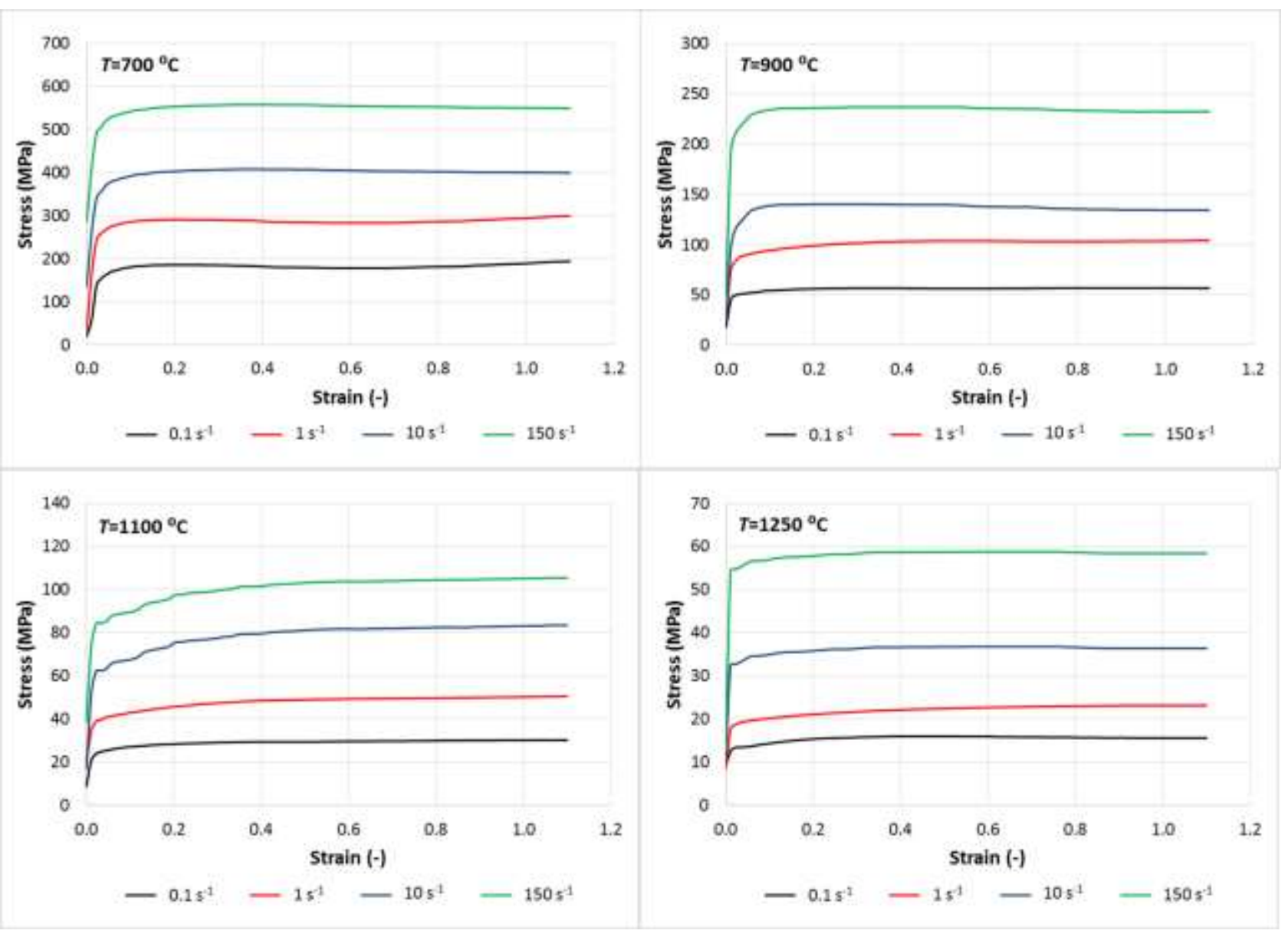

Figure 2 Curves of the dependence of flow stress on the true strain $\left(T=700 \div 1250^{\circ} \mathrm{C} ; \dot{\varepsilon}=0,1 \div 150 \mathrm{~s}^{-1}\right)$

\section{CONDUCTING RESEARCH BY MATHEMATICAL MODELING}

Based on the results of physical modeling, mathematical model was developed in the "Deform 3D" program, which repeats plane-strain compression tests to check the adequacy of the model. During developing the model, only the solution of the deformation problem was taken, and therefore the influence of the external environment, as well as the increase and loss of heat during modeling were not taken into account, the sample temperature remained constant.

Since the physical modeling was carried out at constant strain rates, the speed of movement of the top die varied in time. Using the equations from work [7], as well as data on the reduction of the distance between the dies, a graph of the dependence of the die movement speed on the time of the experiment at a constant strain rate was obtained, which was also introduced into the model. The coefficient of friction on the contact surfaces was taken as 0.05 .

The comparison of the results of physical and mathematical modeling was carried out on the basis of the dependence of the force acting on the die on the deformation time. The "Model before correction" curves in Figure 3 were obtained as a consequence of the direct transfer of the physical modeling results. For obtaining adequate data the influence of various factors on the flow stress versus true strain curves during the research was analyzed. Using the methods from the works [8-9], repeated correction of the data obtained in physical modeling was carried out, after that repeated modeling was performed. As a result, new dependences of the 
force on the deformation time were obtained, which are presented in Figure 3 "Model after correction". A comparison of the measured curves of the dependence of the flow stress on the true strain, obtained in laboratory researches and the corrected, is shown in Figure 4. The discrepancy between the results of physical and mathematical modeling does not exceed $10 \%$, which indicates the adequacy of the developed model.
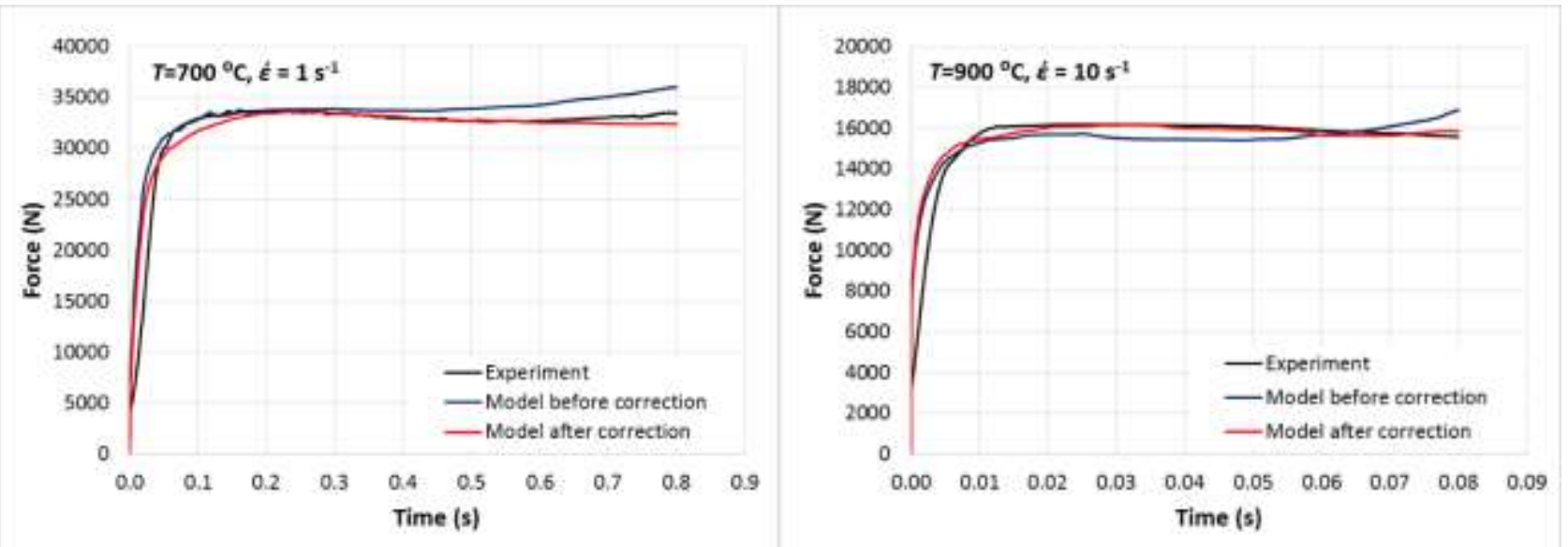

Figure 3 Dependence of the force acting on the die on the time of deformation

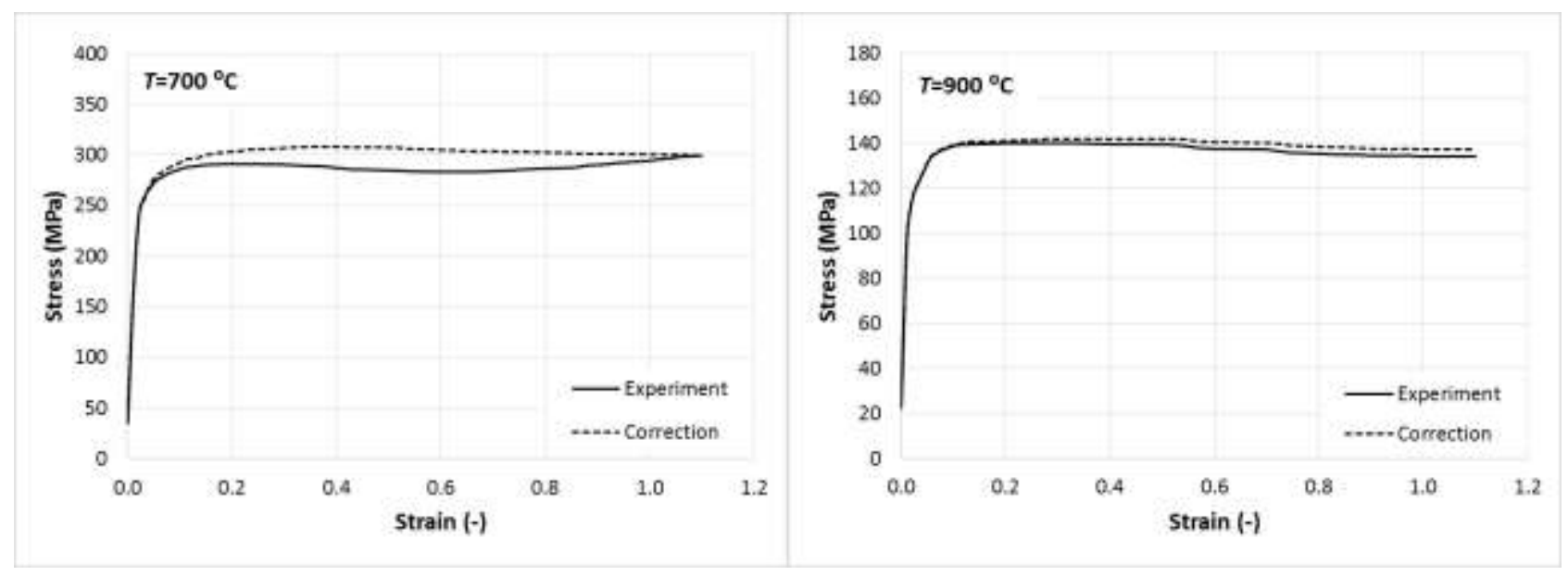

Figure 4 Comparison of curves of dependence flow stress of metal on true strain obtained by methods of physical and mathematical modeling $\left(T=700^{\circ} \mathrm{C} ; \dot{\varepsilon}=1 \mathrm{~s}^{-1}\right.$ and $\left.T=900^{\circ} \mathrm{C} ; \dot{\varepsilon}=10 \mathrm{~s}^{-1}\right)$

For strain rate of $150 \mathrm{~s}^{-1}$ the curves were interpolated from data obtained for a strain rate of $10 \mathrm{~s}^{-1}$. This is due to the difficulties encountered in the course of data processing. The processes occurring during deformation under these conditions are features of the material and are not fully reflected in the experimental results, and therefore additional research is required.

\section{CONCLUSION}

Experimental studies have been carried out on the Gleeble 3800 for an electrical steel grade. The curves of the dependence of flow stress of metal on the true strain are obtained.

The mathematical model is developed that repeats the plane-strain compression test. The comparison of the results of physical and mathematical modeling was carried out on the basis of the dependence of the force acting on the die on the deformation time. For adapt the model the results from the experiments were adjusted, the discrepancy does not exceed $10 \%$. 
The obtained curves of the dependence of the flow stress of the metal on the true deformation can be used to analyze the technological modes of hot rolling of electrical steel grades, and the developed mathematical model can be used to simulate the thermal state of the metal during the formation of inhomogeneity of properties on long flat products.

\section{ACKNOWLEDGEMENTS}

The reported study was funded by RFBR according to the research project № 20-38-90232

\section{REFERENCES}

[1] KAZADZHAN, L.B. Magnitnye svojstva elektrotekhnicheskih stalej i splavov. Moskva: Nauka i tekhnologii, 2000.

[2] SAFRONOV, A.A., BELSKIY, S.M., FILATOV, A.N. Study of the microstructure of electrotechnikal anisotropic steel with accelerated cooling. Procedia Manufacturing. 2019, vol. 37, pp. 236-238.

[3] KAN, R.U., HAAZEN, P.T. Fizicheskoe metallovedenie: v 3-h t., izd., pererab. i dop. Moskva: Metallurgiya,1987.

[4] PUZANOV, M.P. Issledovanie napryazhenno-deformirovannogo sostoyaniya processa listovoj prokatki transformatornoj stali s uchetom anizotropii svojstv. Ekaterinburg, 2019. Dissertation. URFU im. B.N. Elcina.

[5] Dynamic Systems Inc. Available from: https://www.gleeble.com

[6] LOVEDAY, M.S., MAHON, G.J., ROEBUCK, B., LACEY, A.J., PALMIERE, E.J., SELLARS, C.M., M.R. VAN DER WINDER. Measurement of flow stress in hot plane strain compression tests. Materials at High Temperature. 2006, vol. 23, no. 2, pp. 85-118.

[7] AKSENOV, S.A. Avtomatizirovannaya sistema proektirovaniya $i$ analiza texnologicheskix processov prokatki $v$ kalibrax. Moskva, 2010. Dissertation. MGIEM.

[8] DYJA, H., KNAPINSKI, M., KAWALEK, A., KWAPISZ, M., BANASZEK, G. Hardening curves of micro-alloy steel for production of strength grade X80 plate. In: Sbornik dokladov Mezdunarodnoj naucno-tehniceskoj konferencii. Moskva, 2011, pp. 139-149.

[9] KWAPISZ, M. Numeryczne modelowanie proby jednoosiowego sciskania testu systemu Gleeble 3800. Hutnik, Wiadomosci Hutnicze. 2016, vol.83, no 11, pp. 504-506. 